\title{
8. Accountability mechanisms: the case of the European banking union
}

Mattia Guidi

\section{INTRODUCTION}

Accountability is an increasingly popular concept in policy-making and in social sciences (Flinders, 2001; Koop, 2011; Maggetti, Ingold and Varone, 2013; Fernández i Marín, Jordana and Bianculli, 2015; Koop and Hanretty, 2018). Its importance has grown together with the complexity of policy-making. As policy-making turns out to be more and more technical and increasingly delegated to experts, the question of how citizens, political bodies, stakeholders can assess and influence policy-making has become crucial. Democracy cannot be conceived without proper access to information, and without the possibility to engage with policy-makers and steer their behaviour. Yet, there are technical and political obstacles to putting the apparently uncontested concept of accountability into practice.

Accountability, in particular, seems to be at odds with other goals of policy-making (efficiency, credibility, consistency) that instead are meant to require policy-makers to be insulated from political control, and thus from political accountability as well. Therefore, the institutional design of new bodies is never simply about maximizing the number of accountability mechanisms, but rather about striking a balance between conflicting goals.

To better understand how policy-makers find a particular equilibrium in this trade-off, this chapter analyses a recent instance of policy change (and institutional change) that took place at EU level: the establishment of the European banking union. At the moment, the banking union is composed of two policies: a Single Supervisory Mechanism (SSM) and a Single Resolution Mechanism (SRM) (see Fabbrini and Guidi, 2018 for a more detailed analysis). There are plans to complete the banking union with a European Deposit Insurance Scheme, but this is currently under negotiation. The SSM (created with Council Regulation 1024/2013, 'SSM Regulation' henceforth) consists of a system of centralized supervision for all the main banks of the Eurozone. Supervision is exercised by the European Central Bank (ECB) in collaboration 
with national supervisory authorities. The SRM (created through Regulation 806/2014, 'SRM Regulation' henceforth) has instead been established to deal with banks that are 'failing or. . .likely to fail' (Article 18.1 SRM Regulation).

Both policies aim at minimizing the risk of banking crises, which have been one of the main causes of the European sovereign debt crises. On the one hand, unreliable banking supervision by national authorities has brought some financial institutions in several European countries close to bankruptcy. On the other, the need for national governments to save failing banks has resulted in increased government deficit and debt, which in turn fuelled a large-scale credibility crisis for several Eurozone members. The banking union seeks to avoid similar vicious circles in the future. With the SSM, banking supervision should become stricter, and banking crises less likely. With the SRM, the 'resolution' of failing banks should not rely on national governments' (and national taxpayers') money, but on a Single Resolution Fund built with contributions levied on all banks. This, combined with the provision that shareholders must suffer losses before external money is used (the so-called bail-in procedure), should reduce moral hazard and the risk of negative externalities.

The SSM assigns centralized banking supervision to the ECB, and in particular to an internal body named the Supervisory Board (see Section 3.1), appointed by the ECB itself with the participation of Commission and Council. The SRM policies have instead been delegated to a newly created body, the Single Resolution Board (SRB), whose members are appointed by the Commission, the Council and the European Parliament (EP). The SSM and the SRM have a number of significant differences in their institutional design, the appointment of their members, and the external controls on their activities (see Section 3.3 for a detailed analysis). Since they substantially deal with two components of the same policy, these differences are worth examining. This chapter seeks to explain why EU legislators provided for greater political accountability in the SRM than in the SSM. The empirical analysis, based on a comparison of the two policies and of their functions, leads to the conclusion that the main factor explaining the differences in accountability between the two policies is the inherently redistributive nature of the SRM.

The chapter proceeds as follows. Section 2 discusses the concept of accountability and its relationship with regulatory autonomy, the nature of EU agencies, and the possible explanations for the variation in accountability mechanisms observed in the SSM and SRM. Section 3 analyses and compares the provisions relating to accountability in the two policies. Section 4 discusses how the activators included in the two policies could actually trigger mechanisms of accountability, by comparing the EU banking union to EU competition policy. Section 5 provides some concluding remarks. 


\subsection{What is Accountability and Why it Matters}

The concept of accountability has considerably evolved in the last 30 years. From a narrow, intra-organizational definition, scholars have come to consider accountability not just as a concept referring to the interaction between a principal and an agent, but also as a set of mechanisms going in multiple directions: towards political principals, but also towards citizens, interest groups, stakeholders (Fernández i Marín, Jordana and Bianculli., 2015; Jordana, Bianculli and Fernández i Marín, 2015). The most accepted definition of accountability is that of Bovens (2007, p. 450), who defines accountability as 'a relationship between an actor and a forum, in which the actor has an obligation to explain and to justify his or her conduct, the forum can pose questions and pass judgement, and the actor may face consequences'.

Put in this way, accountability is very much connected to the concept of delegation. This is because an actor has been delegated power, within specific limits and with a specific mandate, and that this actor must offer explanation for her or his conduct, and possibly face sanctions. The classical accountability relationship is that between voters and elected politicians: in this sense, 'democratic accountability usually means that voters know. . what parties have done in office and reward or punish them conditional on these actions' (Stokes, 2005, p. 316). However, modern democratic systems have evolved by creating numerous 'chains of delegation' (Strøm, 2000) that go from voters to MPs, from MPs to executives, from executives and from MPs to regulatory agencies, and so forth. When the chain of delegation gets messy, it becomes difficult to determine who must be accountable to whom.

What is more, the creation of regulatory agencies, which has characterized all democracies in the last 30 years (Jordana, Levi-Faur and Fernández i Marín, 2011), poses a fundamental problem for democratic accountability, in that their establishment is not meant to allow for systematic control of their activities, but rather the contrary: they are explicitly granted independence from political principals. The theoretical justification for the independence of regulatory agencies dates back to the seminal contribution of Kydland and Prescott (1977), and it was first applied to the institutional design of central banks (see Barro and Gordon, 1983; Rogoff, 1985). From there, in a spectacular spillover, these ideas spread in the realm of regulation studies - particularly in the 1990s and early 2000s, policy-makers and scholars agreed on the need for non-majoritarian institutions in a growing number of policy fields (see Majone, 1996, 1997, and Guidi, 2015a, 2016 for an overview). 
Independence from political principals is seen as a resource that allows regulatory agencies to implement consistent policies through time, benefit from the expertise of their members, and avoid the risk of political uncertainty (see Guidi, 2016, pp. 66-76). So it is precisely the (relative) lack of accountability that is expected to improve the agencies' regulatory performance - although the relationship between independence and performance has not been unequivocally proven (Voigt, 2009; Buccirossi et al., 2012; Guidi, 2015b; Vining, Laurin and Weimer, 2015). These supposed benefits of independence are at odds with the universally recognized benefits of accountability, which should make policy-makers as responsive as possible to the voters. Can this contradiction be reconciled?

The answer to this question must probably be negative, meaning that there is an unavoidable trade-off between accountability and independence (for a more detailed explanation of this trade-off, see Guidi, 2015a). Therefore, every time politicians need to establish a new agency or bureaucratic body, they have to decide to what extent they want it to be democratically controlled (and, conversely, to what extent they want it to be independent). There are various ways in which democratic accountability can be pursued. Agencies can be accountable to ministers, governments or parliaments through the presentation of annual reports, hearings and other similar tools. Similarly, agencies can be required to make some information available to the public in general, by publishing reports, resolutions or minutes (Fernández i Marín, Jordana and Bianculli, 2015). However, if we recall the definition of accountability that we gave at the beginning of this section, we must notice that the sanctioning element is crucial to it: the mere fact of publishing some information on a website does not necessarily increase the agency's accountability, if those who obtain this information have no means to influence the way the agency behaves.

For the purpose of this volume, it is useful to clarify that accountability can be conceptualized as a second-order mechanism. In fact, rules define certain activators that enable political principals to exercise (first-order mechanism) direct or indirect control on some agency. The presence of these mechanisms (and the threat of using them) is then expected to trigger accountability (second-order mechanism) on behalf of the agency.

\subsection{Accountability in EU Agencies and Banking Regulation}

EU agencies, like those created in the context of the European banking union, can be analysed through their features like national agencies. European agencies are organizations, established by EU legislators, endowed with regulatory tasks and operating with some degree of autonomy from the Commission, the Council and the European Parliament (Keleman, 2002; Dehousse, 2008; Trondal and Jeppesen, 2008; Kelemen and Tarrant, 2011; Mathieu, 2016). They 
were set up to carry out activities for which the Commission lacked the expertise or the staff, or for which the Council (and the European Parliament) wanted to have an enforcer independent from the Commission (Keleman, 2002). The already complex chain of delegation that characterizes EU policy-making has become even more blurred with the emergence of bodies that have the most various tasks, powers, and appointment procedures (Curtin, 2005).

How does accountability relate to the establishment and the activity of EU agencies? Based on the definition of accountability given in the previous section, three main issues deserve attention. The first is which decision-makers participate in the creation of the agency. As the agency would not exist without some legislative act, it is self-evident that the legislators are the "political principals' that decide to make the agency more or less accountable to themselves. The second issue concerns the appointment of the members of the agency, or of its board (however it may be called). As the policy preferences of the appointees are generally known before the appointment, those who appoint the board certainly have an influence on the decisions that the agency will take. Strictly linked to this aspect is the possibility to dismiss members of the agency. Finally, an important aspect to consider is the way in which the decisions of the agency will be 'checked' and constrained by the political principals. Depending on a variety of factors, those who delegate may decide either to make future interventions in the agency's activity impossible, or to reserve for themselves the possibility to amend or block the agency's decisions.

Concerning the case on which this chapter focuses, it must be noted that the ECB, envisaged with the Maastricht Treaty of 1992 and established in 1998, has several features in common with agencies: its members are appointed among renowned experts in the ECB's field of activity; it enjoys great independence from other EU bodies; it is in charge of carrying out only the specific tasks that are delegated to it. Unlike other agencies, the ECB is explicitly mentioned in the Treaties: for this reason, it cannot be dissolved, and its task of adopting the Eurozone's monetary policy cannot be delegated to any other body, unless all EU member states agree on a treaty change. From this point of view, the ECB is much more 'protected' from interference, and it enjoys a sort of special status.

\subsection{Theoretical Expectations}

What do theories of delegation predict in terms of independence and accountability of regulators? To answer this question, it is useful to start from the distinction between redistributive and regulatory policies (Majone, 1996, p. 5; Hix and Høyland, 2011, pp. 190-91; Levi-Faur, 2011, p. 4). While the first 'aim [is] to improve the conditions of one group in society at the expense of another', the latter aim is to find solutions 'capable of improving the conditions 
of all, or almost all, individuals and groups in society' (Majone, 1996, p. 5). Redistributive policies require decision-makers to determine from whom taxes should be levied and to whom revenues should be distributed. Being zero-sum games, which do not necessarily improve the general welfare of a society, they can be legitimately made only by decision-makers who are granted such power by voters. Differently, regulatory policies can be legitimately taken by non-majoritarian bodies, because they aim at correcting market failures and increasing the overall efficiency of the economic system. Majone summarizes this distinction by claiming that:

the delegation of important policy-making powers to independent institutions is democratically justified only in the sphere of efficiency issues, where reliance on expertise and on a problem-solving style of decision-making is more important than reliance on direct political accountability. Where redistributive concerns prevail, legitimacy can be ensured only by majoritarian means. (Majone, 1997, p. 162)

This distinction, however, is not only normative. It is true that the legitimacy of redistributive decisions taken by independent regulators could be questioned. However, it is also evident that politicians themselves are less willing to delegate when key redistributive issues may arise. This is because where there is redistribution, there are also electoral costs and benefits. Decisions involving transfers of money are more easily perceived by voters, and they can easily yield electoral gains (or losses) for politicians. If a policy is likely to redistribute costs and benefits across groups in a society, politicians will be more likely to keep it. To provide an example related to EU policy-making, consider to what extent national governments have delegated powers in 'regulatory' policies (like competition policy, monetary policy, regulation of the Single Market) and how intergovernmental the approval of the Multiannual Financial Framework has remained.

Beside this distinction, the main reason for granting independence to regulators has been identified with the need to reassure economic actors that a certain policy choice will be implemented consistently through time (Majone, 1996, 1997). The act of delegation to an agency, which is given the power to take decisions that were once made by political bodies (parliaments and/or governments), serves as a signal of credible commitment. The higher the degree of independence granted to an agency, the higher the cost of reneging on the promise made with the act of delegation.

Politicians can also delegate to protect their policy choices from future majorities that could overturn them (Moe, 1990). By insulating a policy from political discretion, policy-makers not only tie their own hands (Giavazzi and Pagano, 1988), but also those of future incumbents. The overall effect is that of making some policies more stable. Scholars have also stressed the importance of putting 
experts in charge of policies 'in informationally intense issue areas' (Franchino, 2004, p. 274), in which politicians do not possess enough knowledge and ability to formulate sound and effective policies (Bawn, 1995). Finally, delegation can be convenient also from an electoral point of view: when a regulator has to take decisions that might be unpopular to voters, it can be useful for politicians to be able to distance themselves from the independent decision-makers, allowing them to avoid blame (Fiorina, 1982; Thatcher, 2002).

How can this theoretical framework help us explain different degrees of political accountability in the two EU policies that were so far created in the framework of the European banking union? The answer is not straightforward, because the bodies in charge of managing the SSM and the SRM perform their activities in the same policy area, with very similar requirements of technical expertise, and their creation happened almost at the same time (the approval of the SRM Regulation was only nine months after that of the SSM Regulation). Therefore, it is difficult to find significant differences that may explain why their degree of political accountability is different. There is, however, one feature that the two policies do not have in common, and which strictly relates to the distinction made at the beginning of this section: while the SSM is based on regulatory activities (like requests for information, investigations, on-site inspections, authorizations to operate in a participating member state, assessments on the acquisition of qualifying holdings in banks ${ }^{1}$ ), the SRM's activities, in that they may imply the use of the Single Resolution Fund to help failing banks 'ensure the continuity of essential financial services' (SRM Regulation, Recital 58), have a redistributive nature. In other words, taxes levied on banks from the whole Eurozone might in future be used to save a bank (or a number of banks) based in a specific country.

In the next sections, I will analyse how the institutions of the European banking union have been designed in terms of activators of accountability mechanisms, focusing in particular on the interplay between the decision-makers during the negotiations. At the end of this analysis, it will be possible to evaluate which institutions are characterized by greater mechanisms of political accountability, and to assess the plausibility of the explanation advanced here.

THE INSTITUTIONAL DESIGN OF THE EUROPEAN BANKING UNION: HOW ACCOUNTABLE ARE THE SUPERVISORY BOARD AND THE SINGLE RESOLUTION BOARD?

As argued in the introduction, the European banking union is meant to be composed of three pillars: (1) a Single Supervisory Mechanism (SSM), passed in October 2013 and entered into force in November 2014; (2) a Single Resolution 
Mechanism (SRM), approved in July 2014 and became operative in January 2016; (3) a European Deposit Insurance Scheme that is still being negotiated. For obvious reasons, this chapter will focus just on the first two pillars.

A first distinction needs to be made with regard to the decision-making procedures for establishing the SSM and the SRM. The SSM has been passed with a procedure involving just the Commission (with its power of legislative initiative) and the Council, acting under unanimity rule. EU legislators were able to use this procedure because Article 127.6 of the Treaty on the Functioning of the European Union (TFEU) envisaged it to "confer specific tasks upon the European Central Bank concerning policies relating to the prudential supervision of credit institutions'. When creating a European system of banking supervision, Commission and Council found a policy that had already been called for in the TFEU, and for which they could use a 'fast-track' procedure (without involving the EP) - provided they chose the ECB as 'agent'.

The SRM case was different in many respects. First, the policy was not explicitly envisaged in the treaties. Therefore, the legal basis was much more uncertain than in the SSM case. The legal basis for the SRM was found in Article 114 TFEU, which deals with 'measures for the approximation of the provisions. . .which have as their object the establishment and functioning of the internal market'. Second, the decision-making procedure prescribed by Article 114 is the ordinary legislative procedure, which means that Council and EP had to find an agreement on a proposal laid down by the Commission. This means one more veto player in the decision, and one more political principal. Third, the SRM in its entirety has been set up by three separate acts: a directive (Directive 59/2014), a regulation (Regulation 806/2014) and an intergovernmental agreement (signed by all the member states that adopt the euro on 14 May 2014).

\subsection{Accountability Provisions Introduced in the Single Supervisory Mechanism}

As explained in the introduction, the supervisory functions of the ECB are performed by an internal body that is formally separated from the Executive Board and the Governing Council that manage monetary policy - the Supervisory Board. The board is composed by six fixed members (among which there are a Chair and a Vice-Chair) and by one representative from each supervisory authority of a participating member state.

Regarding the appointment of the Chair and the Vice-Chair of the Supervisory Board, the legislators have opted for a procedure with shared responsibility of ECB, EP and Council. Although the Council and the EP do not have means to interfere in the Supervisory Board's activity, their participation in the appointment ensures at least some ex ante influence. This influence, however, is rather 
limited, as the candidates for Chair and Vice-Chair are proposed by the ECB itself. The Chair is appointed for five years, and her or his appointment is not renewable. The Vice-Chair, instead, must be selected among the members of the ECB's Executive Board.

A second instrument that can potentially trigger mechanisms of accountability is the presence of a procedure for removing the Chair in case of serious misconduct. Article 26.4 of the SSM Regulation prescribes that '[i]f the Chair of the Supervisory Board no longer fulfils the conditions required for the performance of his duties or has been guilty of serious misconduct, the Council may, following a proposal by the ECB, which has been approved by the European Parliament, adopt an implementing decision to remove the Chair from office'. However, the fact that the proposal to remove the Chair must come from the ECB indicates how far this is from being a substantial check or a constraint on the Supervisory Board's activity.

Finally, other provisions of Regulation 1024/2013 oblige the ECB and the Chair of the Supervisory Board to offer information and participate in hearings when requested. In particular, Article 20 of the SSM Regulation requires the ECB to submit an annual report to the EP, Council, Commission and Eurogroup (Article 20.1). In addition to that, the Chair of the Supervisory Board can be heard by the Eurogroup (Article 20.4), by committees of the EP (Article 20.5), and must reply 'orally or in writing to questions put to it by the European Parliament, or by the Eurogroup' (Article 20.6).

\subsection{Accountability Provisions Introduced in the Single Resolution Mechanism}

The SRM, as we noted above, is composed by three separate legislative acts. Notably, one of them is an intergovernmental agreement, which has been used to prescribe how funds gathered from banks at state level must be merged into a Single Resolution Fund, that the SRB is expected to use in case of a banking crisis. The use of the intergovernmental agreement has been criticized by many commentators, as it would allow any country to withdraw its 'compartment' of the fund if the SRM were changed against its will or applied in a way that the country perceives to represent a 'fundamental change of circumstances' (see Fabbrini and Guidi, 2018). This is not an explicit accountability provision, but it is certainly one that gives participating member states a strong implicit power with regard to the Single Resolution Board.

Which provisions of the SRM are meant to trigger mechanisms of accountability? Concerning the appointment of the members of the SRB, the procedure entails a proposal by the Commission, which is submitted to the EP and, after its approval, to the Council, which ratifies the appointment. The two 
co-legislators are given a substantial veto power on the choice of the members of the SRB (Article 56 SRM Regulation).

Another aspect on which there are relevant checks is the resolution procedure. Although the SRB is autonomous in deciding whether to start a resolution procedure or not, the Commission and the Council have the power to block the resolution scheme or to amend it. This power must be exercised jointly by Commission and Council: this means that if one of the two does not agree with the other's view, nothing is done and the resolution scheme is adopted as the SRB sees fit (Article 18 SRM Regulation). The time for the Commission and the Council to object or amend the proposal is a maximum of 24 hours. It could be argued that having such a short time for amending the resolution scheme makes it less likely for the Commission and the Council to exercise their power.

Regarding accountability and reporting obligations, the SRB has a few more obligations with regard to other actors than the ECB Supervisory Board. It must present its annual report not only to the EP, Council, and Commission, but also to the European Court of Auditors (ECA) and to all the member states' national parliaments (Article 45.2 SRM Regulation). Its Chair cannot be heard by the EP only, but also by the Council (Article 45.4-5). Similarly to the ECB Supervisory Board, it must reply orally or in writing to questions from the EP and the Council (Article 45.6).

Finally, removal of the Chair and of the Vice-Chair is possible with a procedure involving the three main political bodies of the EU: EP, Commission, and Council (Article 56.9).

\subsection{Comparison}

Based on the analysis of the previous sections, we can now compare the accountability provisions present in the SSM and in the SRM. In short, there is no doubt that the Council and EP have a greater control on the SRM than on the SSM. First, the SSM is managed by an internal body of the ECB. The fact of being physically located inside an institution that is by far the most independent of the EU signals how autonomous policy-making is in this field. Indeed, for the SSM there was no need (and no political will) to create a new body: the ECB was delegated an additional power, and this came with few checks on the Supervisory Body's activity.

The only institutional feature that allows for some influence of the Council and of the EP in the Supervisory Body's status is their involvement in the appointment of the Chair and of the Vice-Chair. However, it must be noted that the ECB remains a veto player, as the actor that proposes candidates in the first place. Therefore, the room for external, 'political' influence of the Supervisory Body is minimal. 
Also regarding policy-making, the ECB is completely autonomous from 'democratic' bodies like the EP and the Council, as well as from the Commission. Its supervisory activities are not controlled, authorized, or checked by any other EU institution. The ECB's Supervisory Body decides under majority rule, with the Chair having a casting vote in case of a tie (Article 26.6 SSM Regulation). Finally, although removal of the Chair of the Supervisory Board is theoretically possible, the fact that it must be requested by the ECB itself excludes any 'political' removal, and it restricts this tool to cases of serious personal misconduct - very unlikely to arise.

The SRM, in contrast, appears more permeable by political bodies. First of all, it is a 'de novo body' (see Bickerton, Hodson and Puetter, 2015, p. 705): the member states decided not to delegate further regulatory powers to the Commission or the ECB - though they could have done that, in principle. This means that it cannot benefit from the 'institutional shield' of a powerful body like the ECB: its autonomy depends exclusively on the rules that protect it and on the way in which it will carry out its tasks.

The appointment of the members of the SRB is also different from what we observe in the SSM. First, while in the SSM only the Chair and the Vice-Chair are appointed by bodies that are external to the ECB (and the Vice-Chair is bound to be a member of the Executive Board of the ECB), here six members are appointed. Second, in the appointment of the six members of the SRB there is no involvement of 'internal' actors, as was the case in the SSM. Commission, Council and EP are free to choose whoever they want, without taking into account the SRB or the ECB's preferences.

Also regarding checks on the regulators' activity, the SRB is more constrained than the Supervisory Body of the ECB. The SRM Regulation provides for a specific procedure to be followed in case Commission and Council want to object to, or to amend, a proposal of the resolution scheme drafted by the SRB. Obviously, there is an objective limitation on the use of this tool - because their power can only be exercised jointly, the Commission and the Council must agree on the objections they make to the SRB's scheme. Objections or amendments must be proposed by the Commission and confirmed by the Council. If the Commission's concerns are not shared by the Council, the procedure will not be stopped. Similarly, if the Council has objections but the Commission does not share its concerns, no intervention will occur. However, the fact that this intervention is always possible constitutes a relevant check on the SRB, which must always make sure not to deviate too much from the joint preferences of Commission and Council.

Finally, removal of the Chair and the Vice-Chair of the SRB is possible, and it must not be requested or authorized by the body itself. We can thus say that this procedure, which requires the agreement of EP, Commission and Council, is more likely to be activated in the SRM than in the SSM. That said, the 
Table 8.1 Accountability of regulators to EU legislators in the Single Supervisory Mechanism and Single Resolution Mechanism

\begin{tabular}{lll}
\hline & $\begin{array}{l}\text { Single Supervisory Mechanism } \\
\text { (Supervisory Board) }\end{array}$ & $\begin{array}{l}\text { Single Resolution Mechanism (Single } \\
\text { Resolution Board) }\end{array}$ \\
\hline $\begin{array}{l}\text { Institutional status } \\
\text { of regulator }\end{array}$ & $\begin{array}{l}\text { Internal body of the ECB } \\
(-)\end{array}$ & $\begin{array}{l}\text { Ad hoc agency } \\
(+)\end{array}$ \\
\hline $\begin{array}{l}\text { Appointment of } \\
\text { regulators }\end{array}$ & $\begin{array}{l}\text { Only Chair and Vice-Chair appointed } \\
\text { by EP and Council (but with the ECB) } \\
(-)\end{array}$ & $\begin{array}{l}\text { Six members appointed by EP, Commission } \\
\text { and Council } \\
(+)\end{array}$ \\
\hline $\begin{array}{l}\text { Checks on } \\
\text { regulatory activity }\end{array}$ & $\begin{array}{l}\text { None } \\
(-)\end{array}$ & $\begin{array}{l}\text { Resolution schemes can be amended or } \\
\text { rejected by Commission and Council } \\
(+)\end{array}$ \\
\hline $\begin{array}{l}\text { Removal of } \\
\text { regulators }\end{array}$ & $\begin{array}{l}\text { Possible for Chair only (requested } \\
\text { by the ECB itself, decided by EP and } \\
\text { Council) } \\
(-)\end{array}$ & $\begin{array}{l}\text { Possible for Chair and Vice-Chair (decided } \\
\text { by Commission, EP and Council) } \\
(+)\end{array}$ \\
\hline $\begin{array}{l}\text { Transparency } \\
\text { and information } \\
\text { provisions }\end{array}$ & $\begin{array}{l}\text { Annual report (to EP, Council, } \\
\text { Commission, Eurogroup), can be } \\
\text { heard by the EP, must reply to } \\
\text { questions from EP and Eurogroup } \\
(-)\end{array}$ & $\begin{array}{l}\text { Annual report (to EP, national parliaments, } \\
\text { Council, Commission, ECA), can be heard } \\
\text { by EP and Council, must reply to questions } \\
\text { from EP and Council } \\
(+)\end{array}$ \\
\hline
\end{tabular}

language of Article 56.9 of SRM Regulation seems to exclude dismissals for 'political' conflicts, by specifying that removal of the Chair and Vice-Chair is possible when he or she 'no longer fulfil the conditions required for the performance of his or her duties or has been guilty of serious misconduct'.

\section{FROM ACTIVATORS TO MECHANISMS: CAN ACCOUNTABILITY BE TRIGGERED?}

In the previous section we have seen which activators (see introduction to this volume) have been put in place by EU legislators in designing the banking union. The presence of these activators, however, does not necessarily trigger accountability mechanisms. The reason for not having real accountability can be twofold: on the one hand, it may be because activators are weak (meaning that they do not assign strong powers of sanction or intervention); on the other, there might be a lack of political will to intervene, due to the sensitive nature of the policy and the unwillingness to not interfere with the body. In this section we will analyse how accountability can be triggered with the existing activators in a policy field like the EU banking union. In doing so, it will be useful to refer to a more established EU policy like competition policy. 
The institutional set-up of EU competition policy very much resembles that of the banking union. First, the power to implement the policy, as envisaged in the Treaties since 1957, has been delegated to an existing body: the European Commission. Second, the actual decision-making process takes place in an internal body: like the Supervisory Board within the ECB, DG Competition (DG COMP) within the Commission deals with every aspect of enforcement. Third, the body in charge of the policy enjoys a sort of 'monopoly of information' with regard to other bodies (Cini, 1997). Fourth, competition policy is enforced with a decentralized system: like the EU bodies in charge of banking supervision and resolution work with national authorities, the DG COMP works with national competition authorities (Guidi, 2016).

The way a policy like competition policy has evolved since its establishment (in 1962) can offer a good basis for predicting the evolution, in terms of accountability, of the banking union. Although competition policy has not always enjoyed a prominent status, especially until the mid-1980s, its insulation from the influence of the Council and the EP allowed the competition commissioners to pursue an autonomous agenda (Cini and McGowan, 1998). The DG COMP's independence from the Commission, and subsequently from the member states and the EP, was further strengthened by the 2003 reform (Wilks, 2005). The only real check on the DG COMP has been, historically, the Court of Justice of the EU, before which infringement decisions issued by the Commission can be brought. However, jurisdictional checks are not proper mechanisms of democratic accountability.

Although the banking union is still in its infancy, the first steps do not show any relevant influence exercised by the political body of the EU on the process. As far as the SSM is concerned, the ECB has adopted a series of decisions ${ }^{2}$ aimed at speeding up decision-making by delegating many technical decisions to lower-level offices inside the ECB. Although this responds to a logic of efficiency and efficacy, it contributes to making decision-making even less transparent to external actors and bodies. Regarding the SRM, the first resolution decision authorized by the Single Resolution Body (concerning the Banco Popular Español ${ }^{3}$ ) has been passed with no objections by the Commission. The press release announcing the 'green light' by the Commission shows that the Commission has provided a mere 'procedural' check. ${ }^{4}$ The decision of the Commission to not object to the SRB's proposal has not allowed the Council to debate the resolution scheme.

What is left for accountability in such a system? Very little, it seems. For the good or for the bad, the activators included in these policies that should trigger second-order accountability mechanisms require considerable effort to be activated. This is a feature that the EU banking union has in common with other EU policies, like competition policy (as we have briefly seen above) or monetary policy. Thus, we observe that in these policies EU legislators seem to choose 
to exert little or no control on the enforcers. It must be stressed, however, that we have not yet seen the SRB use the Single Resolution Fund to 'rescue' some bank. Given that redistributive issues appear to explain the relatively stronger accountability activators in the SRM, it might be that the perspective of a substantial redistribution might increase the pressure to activate them.

\section{$5 \quad$ CONCLUSIONS}

This chapter has highlighted that accountability activators go beyond the mere disclosure of information, or the publication of reports. They include all aspects of relationships of delegation in which principals can exercise some form of control, check, influence on the agent. What is more, mechanisms of implicit accountability (giving principals powers that they do not necessarily use) can be more effective than hearings and reports.

It has been shown that redistributive aspects are important in explaining the degree of accountability that legislators want to impose on agencies. Regarding the activators of accountability mechanisms included in the institutional design of the EU banking union, this chapter has illustrated that the Single Resolution Mechanism envisages instruments that allow more accountability to legislators than the Single Supervisory Mechanism. Regardless of the fact that even 'pure' regulatory policies have redistributive implications, EU politicians are less likely to give up control when a delegated policy may entail transfers of money from one country to another. It is not clear whether this is good or bad for the quality of enforcement, especially in a policy that has just been established and still finds itself in a transitional phase. To make such an assessment, we will have to analyse how banking resolutions, especially those involving the use of shared funds (and therefore some form of 'covert redistribution'), will be practically carried out under the new rules.

Evidence from other policy fields with similar institutional set-ups suggests that accountability mechanisms will be activated rarely, and without substantial influence on the decision-making process. Comparing the banking union to competition policy leads us to expect that there will be little accountability of the newly created bodies to the EU legislators. Overall, it appears that accountability mechanisms are not the primary goal of legislators in these policy fields, and the design of these policies rather aims at making the decision-making bodies independent from legislators, to ensure credibility and consistency of policy-making.

\section{NOTES}

1. See Articles $10-15$ of SSM Regulation. 
2. Decision (EU) 2017/933 of the European Central Bank of 16 November 2016, Decision (EU) 2017/934 of the European Central Bank of 16 November 2016, Decision (EU) 2017/935 of the European Central Bank of 16 November 2016, Decision (EU) 2017/936 of the European Central Bank of 23 May 2017, Decision (EU) 2017/937 of the European Central Bank of 23 May 2017.

3. See details at: $<\mathrm{https}: / /$ srb.europa.eu/en/node/315, accessed 14 October $2018>$.

4. See at: <http://europa.eu/rapid/press-release_IP-17-1556_en.htm>, accessed 14 October 2018.

\section{REFERENCES}

Barro, R.J. and D.B. Gordon (1983), 'Rules, discretion and reputation in a model of monetary policy', Journal of Monetary Economics, 12(1), 101-21.

Bawn, K. (1995), 'Political control versus expertise: Congressional choices about administrative procedures', The American Political Science Review, 89(1), 62-73.

Bickerton, C.J., D. Hodson and U. Puetter (2015) 'The new intergovernmentalism: European integration in the post-Maastricht era', JCMS: Journal of Common Market Studies, 53(4), 703-22.

Bovens, M. (2007), 'Analysing and assessing accountability: A conceptual framework', European Law Journal, 13(4), 447-68.

Buccirossi, P., L. Ciari and T. Duso et al. (2012), 'Competition policy and productivity growth: An empirical assessment', Review of Economics and Statistics, 95(4), 1324-36.

Cini, M. (1997), 'Administrative culture in the European Commission: The cases of competition and environment', in N. Nugent (ed.), At the Heart of the Union, Basingstoke: Palgrave Macmillan, pp. 71-88.

Cini, M. and L. McGowan (1998), Competition Policy in the European Union, Basingstoke: Palgrave Macmillan.

Curtin, D. (2005), 'Delegation to EU non-majoritarian agencies and emerging practices of public accountability', in D. Geradin, R. Muñoz and N. Petit (eds), Regulation Through Agencies in the EU: A New Paradigm of European Governance, Cheltenham, UK and Northampton, MA, USA: Edward Elgar Publishing, pp. 88-119.

Dehousse, R. (2008), 'Delegation of powers in the European union: The need for a multi-principals model', West European Politics, 31(4), 789-805.

Fabbrini, S. and M. Guidi (2018), 'The European banking union: A case of tempered supranationalism?', in S. Grundmann and H.W. Micklitz (eds), The European Banking Union and Constitution: Beacon for Advanced Integration or Death-knell for Democracy, Oxford: Hart Publishing, pp. 219-38.

Fernández i Marín, X., J. Jordana and A. Bianculli (2015), 'When accountability meets regulation', in A. Bianculli, X. Fernández i Marín and J. Jordana (eds), Accountability and Regulatory Governance: Audiences, Controls 
and Responsibilities in the Politics of Regulation, Basingstoke: Palgrave Macmillan, pp. 23-50.

Fiorina, M.P. (1982), 'Legislative choice of regulatory forms: Legal process or administrative process?', Public Choice, 39(1), 33-66.

Flinders, M.V. (2001), The Politics of Accountability in the Modern State, Farnham: Ashgate.

Franchino, F. (2004), 'Delegating powers in the European Community', British Journal of Political Science, 34(2), 269-93.

Giavazzi, F. and M. Pagano (1988), 'The advantage of tying one's hands: EMS discipline and Central Bank credibility', European Economic Review, 32(5), 1055-75.

Guidi, M. (2015a), 'Modelling the relationship between independence and accountability of regulatory agencies', in A. Bianculli, X. Fernández i Marín and J. Jordana (eds), Accountability and Regulatory Governance: Audiences, Controls and Responsibilities in the Politics of Regulation, Basingstoke: Palgrave Macmillan, pp. 105-22.

Guidi, M. (2015b), 'The impact of independence on regulatory outcomes: The case of EU competition policy', JCMS: Journal of Common Market Studies, 53(6), 1195-213.

Guidi, M. (2016), Competition Policy Enforcement in EU Member States: What Is Independence For?, Basingstoke: Palgrave Macmillan.

Hix, S. and D.B. Høyland (2011), The Political System of the European Union, 3rd edition, Basingstoke: Palgrave Macmillan.

Jordana, J., A. Bianculli and X. Fernández i Marín (2015), 'When accountability meets regulation', in A. Bianculli, X. Fernández i Marín and J. Jordana (eds), Accountability and Regulatory Governance: Audiences, Controls and Responsibilities in the Politics of Regulation, Basingstoke: Palgrave Macmillan, pp. 1-22.

Jordana, J., D. Levi-Faur and X. Fernández i Marín (2011), 'The global diffusion of regulatory agencies channels of transfer and stages of diffusion', Comparative Political Studies, 44(10), 1343-69.

Keleman, D.R. (2002), "The politics of "Eurocratic" structure and the new European agencies', West European Politics, 25(4), 93-118.

Kelemen, R.D. and A.D. Tarrant (2011), 'The political foundations of the Eurocracy', West European Politics, 34(5), 922-47.

Koop, C. (2011), 'Explaining the accountability of independent agencies: The importance of political salience', Journal of Public Policy, 31(2), 209-34.

Koop, C. and C. Hanretty (2018), 'Political independence, accountability, and the quality of regulatory decision-making', Comparative Political Studies, 51(1), 38-75.

Kydland, F.E. and E.C. Prescott (1977), 'Rules rather than discretion: The inconsistency of optimal plans', The Journal of Political Economy, 85(3), 473-91. 
Levi-Faur, D. (2011), 'Regulation and regulatory governance', in D. Levi-Faur (ed.), Handbook on the Politics of Regulation, Cheltenham, UK and Northampton, MA, USA: Edward Elgar Publishing, pp. 3-24.

Maggetti, M., K. Ingold and F. Varone (2013), 'Having your cake and eating it, too: Can regulatory agencies be both independent and accountable?', Swiss Political Science Review, 19(1), 1-25.

Majone, G. (ed.) (1996), Regulating Europe, London/New York: Routledge.

Majone, G. (1997), 'From the positive to the regulatory state: Causes and consequences of changes in the mode of governance', Journal of Public Policy, 17(2), 139-67.

Mathieu, E. (2016), 'When Europeanization feeds back into EU governance: EU legislation, national regulatory agencies, and EU regulatory networks', Public Administration, 94(1), 25-39.

Moe, T.M. (1990), 'Political institutions: The neglected side of the story', Journal of Law, Economics, \& Organization, 6 (Special Issue: Papers from the Organization of Political Institutions Conference), S213-S253.

Rogoff, K. (1985), 'The optimal degree of commitment to an intermediate monetary target', The Quarterly Journal of Economics, 100(4), 1169-89.

Stokes, S.C. (2005), 'Perverse accountability: A formal model of machine politics with evidence from Argentina', American Political Science Review, 99(3), 315-25.

Strøm, K. (2000), 'Delegation and accountability in parliamentary democracies', European Journal of Political Research, 37(3), 261-90.

Thatcher, M. (2002), 'Delegation to independent regulatory agencies: Pressures, functions and contextual mediation', West European Politics, 25(1), 125-47.

Trondal, J. and L. Jeppesen (2008), 'Images of agency governance in the European Union', West European Politics, 31(3), 417-41.

Vining, A.R., C. Laurin and D. Weimer (2015), 'The longer-run performance effects of agencification: Theory and evidence from Québec agencies', Journal of Public Policy, 35(2), 193-222.

Voigt, S. (2009), 'The effects of competition policy on development cross-country evidence using four new indicators', Journal of Development Studies, 45(8), 1225-48.

Wilks, S. (2005), 'Agency escape: Decentralization or dominance of the European Commission in the modernization of competition policy?', Governance, 18(3), 431-52. 